\title{
Evidence of association with type 1 diabetes in the SLC11A1 gene region
}

Jennie HM Yang*, Kate Downes, Joanna MM Howson, Sarah Nutland, Helen E Stevens, Neil M Walker and John A Todd ${ }^{*}$

\begin{abstract}
Background: Linkage and congenic strain analyses using the nonobese diabetic (NOD) mouse as a model for human type 1 autoimmune diabetes (T1D) have identified several NOD mouse Idd (insulin dependent diabetes) loci, including Slc11a1 (formerly known as Nramp1). Genetic variants in the orthologous region encompassing SLC11A1 in human chromosome 2 q35 have been reported to be associated with various immune-related diseases including T1D. Here, we have conducted association analysis of this candidate gene region, and then investigated potential correlations between the most T1D-associated variant and RNA expression of the SLC11A1 gene and its splice isoform.

Methods: Nine SNPs (rs2276631, rs2279015, rs1809231, rs1059823, rs17235409 (D543N), rs17235416 (3'UTR), rs3731865 (INT4), rs7573065 (-237 C $\rightarrow$ T) and rs4674297) were genotyped using TaqMan genotyping assays and the polymorphic promoter microsatellite (GT)n was genotyped using PCR and fragment length analysis. A maximum of 8,863 T1D British cases and 10,841 British controls, all of white European descent, were used to test association using logistic regression. A maximum of 5,696 T1D families were also tested for association using the transmission/disequilibrium test (TDT). We considered $P \leq 0.005$ as evidence of association given that we tested nine variants in total. Upon identification of the most T1D-associated variant, we investigated the correlation between its genotype and SLC11A1 expression overall or with splice isoform ratio using 42 PAXgene whole blood samples from healthy donors by quantitative PCR (qPCR).

Results: Using the case-control collection, rs3731865 (INT4) was identified to be the variant most associated with $\operatorname{T1D}\left(P=1.55 \times 10^{-6}\right)$. There was also some evidence of association at $r s 4674297\left(P=1.57 \times 10^{-4}\right)$. No evidence of disease association was obtained at any of the loci using the family collections ( $\left(P_{\mathrm{TDT}} \geq 0.13\right)$. We also did not observe a correlation between rs3731865 genotypes and SLC11A1 expression overall or with splice isoform expression.
\end{abstract}

Conclusion: We conclude that rs3731685 (INT4) in the SLC11A1 gene may be associated with T1D susceptibility in the European ancestry population studied. We did not observe a difference in SLC11A1 expression at the RNA level based on the genotypes of rs3731865 in whole blood samples. However, a potential correlation cannot be ruled out in purified cell subsets especially monocytes or macrophages.

\section{Background}

Type 1 diabetes (T1D) is a heritable polygenic autoimmune disease in which both genetic and environmental factors contribute to pathogenesis. To date over 50 loci have been identified that affect risk of T1D [1-3]. The causal genes, variants and haplotypes involved within many of these regions have yet to be identified.

\footnotetext{
* Correspondence: jennie.yang@cimr.cam.ac.uk; john.todd@cimr.cam.ac.uk Juvenile Diabetes Research Foundation/Wellcome Trust Diabetes and Inflammation Laboratory, Cambridge Institute for Medical Research,

University of Cambridge, Addenbrooke's Hospital, Hills Road, Cambridge, CB2
} OXY UK

(c) 2011 Yang et al; licensee BioMed Central Ltd. This is an Open Access article distributed under the terms of the Creative Commons Attribution License (http://creativecommons.org/licenses/by/2.0), which permits unrestricted use, distribution, and reproduction in any medium, provided the original work is properly cited.
The nonobese diabetic (NOD) mouse develops autoimmune insulin-dependent diabetes spontaneously, which resembles human T1D, and has been widely used to study and map non-MHC T1D loci. The loci identified in the NOD mouse as high priority candidates for human T1D studies include solute carrier family 11 member 1 (Slc11a1), which was formerly known as natural resistance-associated macrophage protein 1 (Nramp1) [4]. Slc11a1 is encoded in the Idd5.2 region on mouse chromosome 1 . The NOD strain with the disease-predisposing allele expresses the functional protein, whereas the T1Dresistant B10 strain does not $[5,6]$. The NOD allele was

\section{Biomed Central}


originally identified as providing resistance to bacterial infections in mice. Kissler et al. used RNA interference to reduce Slc11a1 expression in vivo in NOD mice, and found that this reduced the frequency of T1D, mimicking the protective Idd5.2 T1D-resistant haplotype [7]. Furthermore, Slc11a1 was found to augment activation of a diabetogenic $\mathrm{T}$-cell clone by enhancing the processing and presentation of pancreatic islet antigens, such as glutamic acid decarboxylase $\mathrm{GAD}_{65}$, in dendritic cells (DCs) [8].

In humans, SLC11A1 is $14 \mathrm{~kb}$ in length with 15 exons. The gene is located in an approximately $400 \mathrm{~kb}$ region of high linkage disequilibrium (LD) on chromosome 2 q35. The human and mouse SLC11A1 protein sequences have a high degree of conservation, with $88 \%$ identity and $93 \%$ overall sequence similarity [9]. SLC11A1 is expressed in monocytes $[10,11]$, which are the circulating precursors of macrophages and DCs, the major antigen-presenting cells in the immune system. SLC11A1 has pleiotropic effects on macrophage function, all of which are important in resistance to intracellular pathogens. These include release of nitric oxide, L-arginine flux, oxidative burst, tumouricidal and antimicrobial activities, as well as upregulation of CXC chemokine $\mathrm{KC}$, tumour necrosis factor- $\alpha$, interleukin- $1 \beta$, inducible nitric oxide synthase and $\mathrm{MHC}$ class II expression $[12,13]$. Roles of monocytes and macrophages have been implicated in the pathogenesis of T1D $[14,15]$. Recently, macrophages have been shown to be one of the major immune cell populations in infiltrated pancreatic islets of autopsy tissues from patients with T1D $[15,16]$, suggesting that macrophages may contribute to the early phase of beta-cell destruction. Together with the evidence showing that over-activation of SLC11A1 could potentially induce and maintain autoimmune diseases, these data make SLC11A1 a candidate gene for autoimmune and immune-mediated disorders, such as T1D. Interestingly, SLC11A1 has been shown to suppress IL-10 production [17], and the gene that encodes IL-10 has recently been associated with T1D susceptibility $[1,18]$, as well as with risk of ulcerative colitis [19] and of systemic lupus erythematosus [20].

Genetic variants in the SLC11A1 gene region have been reported to be associated with various infectious [21-29] and chronic immune diseases, such as T1D [30-33], rheumatoid arthritis (RA) [34-37], juvenile RA (also known as juvenile idiopathic arthritis; JIA) [38,39], sarcoidosis [40], inflammatory bowel disease (IBD) [41-45], Kawasaki disease [46] and multiple sclerosis [47]. More recently, SLC11A1 has also been claimed to be associated with Behcet's syndrome in a Turkish population [48] and esophageal cancer in a South African population [49]. Blackwell et al. identified a potentially functional polymorphic microsatellite with Z-DNA forming dinucleotide repeats in the promoter region of the human SLC11A1 gene $[50,51]$. Allele 3 with the apparent stronger promoter activity that drives higher expression of $S L C 11 A 1$ relative to allele 2 may result in chronic macrophage hyperactivation, thus predisposing to autoimmune diseases, but protecting against infectious diseases (see additional file 1 for microsatellite allele sequences) [51]. However, not all studies have replicated the association of the promoter polymorphism in T1D [31,32]. Indeed, associations at other polymorphisms, such as rs17235409 (D543N), rs17235416 (3'UTR) and rs3731865 (INT4), have been reported in immune-related and infectious diseases [22,23,25-28, $35-37,39,43]$, implying that alternative variants may be causal. In IBD, Zaahl et al. have shown that the SLC11A1 association involves a protective effect of the promoter SNP, rs7573065 (-237 C $\rightarrow$ T) [44]. They previously found that in the presence of allele 3 of the 5 microsatellite, the change from allele $\mathrm{C}$ to $\mathrm{T}$ at $\operatorname{rs} 7573065(-237 \mathrm{C} \rightarrow \mathrm{T})$ lowered the expression of $S L C 11 A 1$, to a similar level as observed with allele 2 of the microsatellite [52]. Combined, these data suggest that both rs7573065 $(-237 \mathrm{C} \rightarrow \mathrm{T})$ and the microsatellite $\left(r^{2}=0.02\right.$ and $D^{\prime}=0.98$ in controls; see additional file 2) together might be associated with disease.

Previously, Maier et al. found no evidence of association of SLC11A1 with T1D using four tag SNPs (rs2276631, rs2279015, rs1059823 and rs1809231), but only 1,709 T1D cases, 1,829 controls and 1,632 families were studied [4]. They also genotyped the non-synonymous SNP (nsSNP) rs17235409 (D543N) and the microsatellite (GT)n in 1,632 families and did not obtain any evidence of association [4]. Nor did they obtain evidence of association with the nsSNP rs17235409 (D543N), which was genotyped in an additional 1,995 cases and 2,101 controls [4]. The genome-wide association study (GWAS) performed by the Wellcome Trust Case Control Consortium (WTCCC) identified a SNP, rs4674297, in MGC50811 (also known as C2orf62), located within the same LD block as SLC11A1 that showed some evidence of association with T1D ( $P=$ 0.0070) [53]. Barrett and colleagues performed a metaanalysis of three GWAS totalling 7,514 cases and 9,045 controls [1]. They found rs4674297 was one of the four most T1D-associated SNPs in the region with $P$-values of around $10^{-4}$ [1]. Following the additional functional support obtained using the NOD mouse model $[7,8]$, we have performed a comprehensive association analysis of sequence polymorphisms in the $S L C 11 A 1$ region in a maximum of 8,863 unrelated T1D cases and 10,841 controls as well as up to 5,696 T1D families in order to identify the most associated, potentially causal, T1D variant(s) and its effect on expression and splicing of the SLC11A1 gene.

\section{Results and discussion}

We genotyped and analysed three of the Maier et al. tag SNPs (rs2276631, rs2279015 and rs1809231 [4]), the nsSNP rs17235409 (D543N), the indel rs17235416 (3’UTR), rs3731865 (INT4), rs7573065 $(-237 \mathrm{C} \rightarrow \mathrm{T})$ and 
rs4674297 in up to 5,878 cases and 6,406 controls (Figure 1 and Table 1). As the promoter microsatellite (GT)n has been suggested to be a functional variant, we genotyped this polymorphism in the maximum number of samples in the collection available at the time, which was 7,894 cases and 7,560 controls (Figure 1 and Table 1). Since rs3731865 (INT4), the indel rs17235416 (3'UTR) and rs4674297 showed the most evidence of association with T1D $(P \leq 0.005$; Figure 1$)$, they were genotyped in our extended case-control collection in an additional 2,985 cases and 4,435 controls to test whether their effects were independent.

We had over $96 \%$ power to detect an effect size of 0.90 , at an alpha level of 0.005 , assuming a multiplicative allelic effects model and a minor allele frequency (MAF) of 0.29 , with a sample size of 8,863 cases and 10,841 controls. rs3731865 (INT4) showed the most evidence of association with T1D $\left(P=1.55 \times 10^{-6}\right.$; OR $=0.90$ (95\% confidence interval (C.I.) 0.86-0.94); Table 1). The support for association with T1D at rs4674297, a SNP identified from the Barrett et al. meta-analysis study $\left(P=2.9 \times 10^{-}\right.$ $\left.{ }^{4}\right)$ [1], was maintained $\left(P=1.57 \times 10^{-4} ; \mathrm{OR}=0.91(95 \%\right.$ C.I. 0.86-0.96); Table 1; 5,897 cases and 5,461 controls in our full dataset of 8,863 cases and 10,841 controls overlapped with 7,514 cases and 9,045 controls in the Barrett et al. meta-analysis study). Our samples were not genotyped at the other three SNPs, rs12471773, rs2290708 and rs3816560, found in the meta-analysis as they are in high LD with the associated SNPs (rs3731865 and rs4674297; $\mathrm{r}^{2}>0.8$ in controls) and so are unlikely to significantly improve the T1D association signal in this region. We found no evidence of associations that were independent of rs3731865 (INT4) $(P>0.007)$.

We obtained no evidence of association with T1D at any of the nine SLC11A1 polymorphisms genotyped with T1D in up to 5,696 families $(P \geq 0.13$; Table 2). For the most T1D-associated SNP, rs3731865 (INT4), the TDT result indicated no association $(R R=1.00$ (0.95-1.06), $P=0.98$; Table 2) despite being genotyped in the largest number of families. This could have been due to a modest level of power (53\%) in the family collections to detect an effect size of $R R=0.90$ with $\mathrm{MAF}$ of 0.26 at an alpha level of 0.005 , assuming a multiplicative allelic effects model. This study had $82 \%$ power at an alpha level of 0.05 .

The 2004 IBD study by Zaahl et al. suggested that the promoter SNP, rs7573065 $(-237 \mathrm{C} \rightarrow \mathrm{T})$, and the microsatellite (GT)n might, in combination, be associated

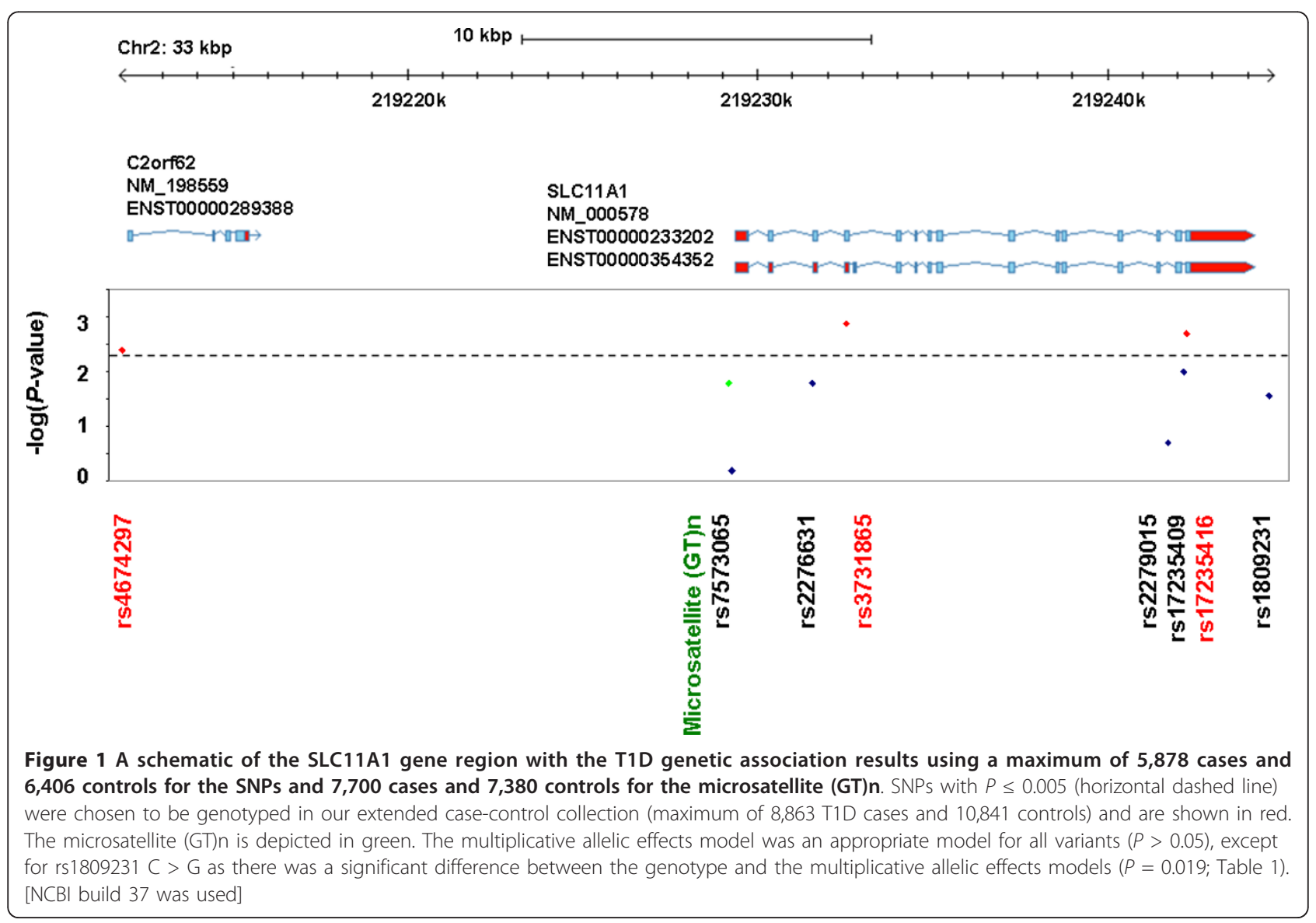


Table 1 Summary of T1D association results for the case-control collection

\begin{tabular}{|c|c|c|c|c|c|c|c|c|}
\hline \multirow[b]{2}{*}{$\begin{array}{l}\text { Variant } \\
\text { [Synonym] } \\
\text { Location }\end{array}$} & \multirow[b]{2}{*}{$\begin{array}{l}\text { Number of } \\
\text { cases }\end{array}$} & \multirow[b]{2}{*}{$\begin{array}{l}\text { Number of } \\
\text { controls }\end{array}$} & \multirow[b]{2}{*}{$\begin{array}{l}\text { Allele or } \\
\text { genotype }\end{array}$} & \multicolumn{2}{|c|}{$\begin{array}{l}\text { Allele or genotype } \\
\text { frequency } N(\%)\end{array}$} & \multirow[b]{2}{*}{ OR } & \multirow[b]{2}{*}{ (95\% C.I.) } & \multirow[b]{2}{*}{$P$-value } \\
\hline & & & & in cases & in controls & & & \\
\hline $\begin{array}{c}\text { rs4674297 G > A } \\
\text { 5' of SLC11A1 }\end{array}$ & 8502 & 10071 & $A$ & $3710(21.82)$ & $4682(23.25)$ & 0.91 & $(0.86-0.96)$ & $1.57 \times 10^{-4}$ \\
\hline within MGC50811 (aka C2orf62) & & & $\mathrm{G} / \mathrm{G}$ & $5210(61.28)$ & $5945(59.03)$ & 1.00 & (reference) & \\
\hline & & & $\mathrm{G} / \mathrm{A}$ & $2874(33.80)$ & $3570(35.45)$ & 0.91 & $(0.86-0.97)$ & \\
\hline$P_{\mathrm{HWE}}=0.050$ & & & $\mathrm{~A} / \mathrm{A}$ & $418(4.92)$ & $556(5.52)$ & 0.84 & $(0.74-0.96)$ & \\
\hline $\begin{array}{c}\text { Microsatellite }(\mathrm{GT}) \mathrm{n} 3>2 \\
\text { Promoter }\end{array}$ & 7697 & 7371 & 2 & 3999 (25.98) & $4010(27.20)$ & 0.94 & $(0.89-0.99)$ & 0.016 \\
\hline & & & $3^{*} / 3^{*}$ & $4195(54.50)$ & $3913(53.09)$ & 1.00 & (reference) & \\
\hline & & & $3 * / 2$ & $3005(39.04)$ & $2906(39.42)$ & 0.96 & $(0.89-1.03)$ & \\
\hline$P_{\mathrm{HWE}}=0.697$ & & & $2 / 2$ & $497(6.46)$ & $552(7.49)$ & 0.85 & $(0.74-0.97)$ & \\
\hline $\begin{array}{l}\mathrm{rs} 7573065 \mathrm{C}>\mathrm{T} \\
{[-237 \mathrm{C}->T]}\end{array}$ & 5649 & 6233 & T & $647(5.73)$ & $732(5.87)$ & 0.97 & $(0.87-1.09)$ & 0.662 \\
\hline Promoter & & & $\mathrm{C} / \mathrm{C}$ & $5018(88.83)$ & $5518(88.53)$ & 1.00 & (reference) & \\
\hline & & & $C / T$ & 615 (10.89) & $698(11.20)$ & 0.97 & $(0.86-1.09)$ & \\
\hline$P_{\text {HWE }}=0.303$ & & & $T / T$ & $16(0.28)$ & $17(0.27)$ & 1.00 & $(0.50-2.00)$ & \\
\hline $\begin{array}{c}\mathrm{rs} 2276631 \mathrm{C}>\mathrm{T} \\
{[274[\mathrm{C} / \mathrm{T}]}\end{array}$ & 5578 & 6048 & T & $2933(26.29)$ & 3331 (27.54) & 0.93 & $(0.87-0.99)$ & 0.016 \\
\hline Exon 3 & & & $\mathrm{C} / \mathrm{C}$ & 2998 (53.75) & 3153 (52.13) & 1.00 & (reference) & \\
\hline & & & $\mathrm{C} / \mathrm{T}$ & 2227 (39.92) & $2459(40.66)$ & 0.94 & $(0.87-1.02)$ & \\
\hline$P_{\text {HWE }}=0.144$ & & & $T / T$ & $353(6.33)$ & $436(7.21)$ & 0.84 & $(0.72-0.98)$ & \\
\hline $\begin{array}{c}\text { rs3731865 G > C } \\
{[469+14[G / C] ; \text { INT4] }}\end{array}$ & 8787 & 10611 & C & 4691 (26.69) & $6116(28.82)$ & 0.90 & $(0.86-0.94)$ & $1.55 \times 10^{-6}$ \\
\hline Intron 4 & & & $\mathrm{G} / \mathrm{G}$ & $4713(53.64)$ & $5401(50.90)$ & 1.00 & (reference) & \\
\hline & & & $\mathrm{G} / \mathrm{C}$ & 3457 (39.34) & 4304 (40.56) & 0.91 & $(0.86-0.97)$ & \\
\hline$P_{\mathrm{HWE}}=0.242$ & & & $\mathrm{C} / \mathrm{C}$ & $617(7.02)$ & $906(8.54)$ & 0.78 & $(0.69-0.87)$ & \\
\hline $\begin{array}{l}\mathrm{rs} 2279015 \mathrm{G}>\mathrm{A} \\
{[1465-85[\mathrm{~A} / \mathrm{G}]]}\end{array}$ & \multicolumn{7}{|c|}{$[1465-85[\mathrm{~A} / \mathrm{G}]]$} & 0.205 \\
\hline Intron 13 & & & $\mathrm{G} / \mathrm{G}$ & $2060(37.12)$ & $2142(36.48)$ & 1.00 & (reference) & \\
\hline & & & $\mathrm{G} / \mathrm{A}$ & $2666(48.04)$ & $2802(47.72)$ & 1.00 & $(0.92-1.08)$ & \\
\hline$P_{\text {HWE }}=0.817$ & & & $\mathrm{~A} / \mathrm{A}$ & $823(14.83)$ & $928(15.80)$ & 0.92 & $(0.82-1.03)$ & \\
\hline $\begin{array}{c}\mathrm{rs} 17235409 \mathrm{G}>\mathrm{A} \\
{[\mathrm{D} 543 \mathrm{~N}]}\end{array}$ & 5498 & 6062 & $A$ & $241(2.19)$ & $216(1.78)$ & 1.28 & $(1.06-1.55)$ & 0.010 \\
\hline Exon 15 & & & $\mathrm{G} / \mathrm{G}$ & $5259(95.65)$ & 5849 (96.49) & 1.00 & (reference) & \\
\hline & & & $\mathrm{G} / \mathrm{A}$ & $237(4.31)$ & $210(3.46)$ & 1.31 & $(1.08-1.59)$ & \\
\hline$P_{\text {HWE }}=0.430$ & & & $\mathrm{~A} / \mathrm{A}$ & $2(0.04)$ & $3(0.05)$ & 0.72 & $(0.12-4.37)$ & \\
\hline $\begin{array}{c}\text { rs17235416 TGTG> del } \\
{[1729+55 \text { del4 [TGTG]; 3'UTR] }}\end{array}$ & 8463 & 9835 & del & $312(1.84)$ & $299(1.52)$ & 1.22 & $(1.04-1.44)$ & 0.015 \\
\hline 3'UTR & & & TGTG/TGTG & $8153(96.34)$ & 9539 (96.99) & 1.00 & (reference) & \\
\hline & & & TGTG/del & $308(3.64)$ & $293(2.98)$ & 1.24 & $(1.05-1.46)$ & \\
\hline$P_{\mathrm{HWE}}=0.624$ & & & del/del & $2(0.02)$ & $3(0.03)$ & 0.69 & $(0.11-4.20)$ & \\
\hline
\end{tabular}


Table 1 Summary of T1D association results for the case-control collection (Continued)

\begin{tabular}{|c|c|c|c|c|c|c|c|c|}
\hline $\begin{array}{c}\text { rs1059823 A > G } \\
{[1801+86[A / G]]} \\
\text { 3'UTR } \\
P_{\text {HWE }}=0.001\end{array}$ & 5,605 & 6,137 & ND & ND & ND & ND & & ND \\
\hline rs1809231 C > G & 5643 & 6151 & G & $4870(43.15)$ & $5399(43.89)$ & 0.97 & $(0.92-1.02)$ & $0.028^{* *}$ \\
\hline \multicolumn{9}{|l|}{3 ' intergenic region } \\
\hline & & & $\mathrm{C} / \mathrm{C}$ & $1783(31.60)$ & $1959(31.85)$ & 1.00 & (reference) & \\
\hline & & & $C / G$ & $2850(50.51)$ & 2985 (48.53) & 1.04 & $(0.96-1.14)$ & \\
\hline$P_{\mathrm{HWE}}=0.249$ & & & $\mathrm{G} / \mathrm{G}$ & $1010(17.90)$ & $1207(19.62)$ & 0.91 & $(0.82-1.01)$ & \\
\hline
\end{tabular}

Association of alleles and genotypes were tested using single locus logistic regression.

* Rare microsatellite alleles (with frequency $<0.1 \%$ ) were combined with the common allele $3 .{ }^{* *}$ The multiplicative allelic effects model was an appropriate model for all variants $(P>0.05)$, except for rs1809231 C>G where a genotype effects model was required $(P=0.019)$. $\left[P_{\mathrm{HWE}}=\mathrm{Hardy}-\right.$ Weinberg equilibrium in controls; OR = odds ratio; $95 \%$ C.I. $=95 \%$ confidence intervals; ND $=$ not done.]

with disease [52]. However, these variants are not associated with T1D, either together in a joint effects model $(P=0.33)$ or individually $(P>0.01$; Table 1$)$. We also assessed whether rs7573065 $(-237 \mathrm{C} \rightarrow \mathrm{T})$ and the microsatellite were involved with T1D susceptibility in a haplotypic manner. Haplotype 3.T (microsatellite.rs7573065) was grouped with all the other haplotypes consisting of the protective allele 2 of the microsatellite, since they were found to exert similar effects on transcriptional activity [52]. Using the most 'susceptible haplotype', 3.C, as the reference, the grouped haplotypes did not show an association with T1D $(P=0.15$; OR $=0.96$ (95\% C.I. 0.90-1.02)). Furthermore, haplotype $3 . \mathrm{T}$ by itself did not confer protection against T1D $(P=0.32$; OR $=0.94$ (95\% C.I. 0.83-1.07)). Together these analyses suggest that rs7573065 $(-237 \mathrm{C} \rightarrow \mathrm{T})$ does not confer protection against T1D, either by itself or in combination with allele 3 of the microsatellite.

SLC11A1 has several known alternative splice transcripts of which the two major isoforms expressed are full length transcripts with or without exon $4 \mathrm{a}$ (74 bp in length). Previous studies have shown that exon $4 \mathrm{a}$, which is located between exon 4 and 5, encoded by an Alu element, is transcribed in vivo but would introduce two termination codons in exon 5 resulting in severely truncated, and thus non-functional, SLC11A1 protein [9]. Interestingly, the most T1D-associated SLC11A1 polymorphism, rs3731865, is located in intron 4, 13 bp 3' of exon 4 and 167 bp 5' of the alternatively spliced exon 4a. Although bioinformatics analyses failed to predict known splice elements around or at rs3731865, due to its location within the gene, we hypothesised that rs3731865 might affect elements for transcription or splicing of SLC11A1 exons. This splicing could cause changes in functional message levels and the amount of functional SLC11A1 protein expressed. Therefore, measuring the ratio of transcripts with or without exon $4 \mathrm{a}$ in the cell population of interest and correlating the expression of SLC11A1 with genotypes of rs3731865 could be informative for determining the effect of this SNP on gene expression.

Table 2 Summary of T1D association results for the family collections

\begin{tabular}{|c|c|c|c|c|c|c|}
\hline Variant & $\begin{array}{l}\text { Number of } \\
\text { families }\end{array}$ & $\begin{array}{c}\text { Number of } \\
\text { informative } \\
\text { transmissions }\end{array}$ & $\begin{array}{l}\text { Minor allele frequency (\%) } \\
\text { in affected siblings }\end{array}$ & $\begin{array}{l}\text { Minor allele frequency (\%) } \\
\text { in unaffected parents }\end{array}$ & $\begin{array}{l}\text { Relative risk } \\
\text { (95\% C.I.) }\end{array}$ & $\begin{array}{c}\text { Family } \\
P_{\text {TDT }}\end{array}$ \\
\hline rs4674297 G>A & NA & NA & NA & NA & NA & NA \\
\hline Microsatellite $(\mathrm{GT}) n 3^{*}>2$ & 1971 & 1925 & 27.02 & 27.06 & $1.00(0.92-1.10)$ & 0.87 \\
\hline rs7573065 C>T & 2472 & 610 & 5.43 & 5.30 & $0.92(0.78-1.08)$ & 0.29 \\
\hline rs2276631 C>T & 2707 & 2587 & 27.38 & 27.15 & $1.00(0.93-1.08)$ & 0.98 \\
\hline rs3731865 G>C & 5010 & 4876 & 26.43 & 26.42 & $1.00(0.95-1.06)$ & 0.98 \\
\hline rs2279015 G>A & 2523 & 2862 & 36.33 & 36.26 & $0.94(0.88-1.02)$ & 0.13 \\
\hline rs17235409 G>A & 1859 & 198 & 2.05 & 2.10 & $0.92(0.70-1.22)$ & 0.57 \\
\hline rs17235416 TGTG>del & 2450 & 191 & 1.61 & 1.65 & $0.85(0.64-1.14)$ & 0.28 \\
\hline rs1059823 A>G & 2591 & 2950 & 39.79 & 38.81 & $1.02(0.95-1.10)$ & 0.56 \\
\hline rs1809231 C>G & 2678 & 3166 & 42.71 & 42.14 & $1.01(0.94-1.08)$ & 0.78 \\
\hline
\end{tabular}

Number of families with genotyping data for the variants in the SLC11A1 gene region with the respective number of informative transmissions, the relative risk and the $P$-value from the transmission/disequilibrium test $\left(P_{\mathrm{TDT}}\right)$. ${ }^{*}$ Rare microsatellite alleles, with frequency $<0.1 \%$, were combined with the common allele 3 ; $95 \%$ C.I. $=95 \%$ confidence interval; $\mathrm{NA}=$ not available $]$ 
SLC11A1 mRNA is expressed specifically in whole blood, CD $14^{+}$monocytes, $\mathrm{CD}_{33^{+}}$and CD66b (granulocytes) myeloid cells according to the microarray expression data available from BioGPS and HaemAtlas $[10,11]$. Since whole blood samples were available in the laboratory, we investigated if the genotypes of rs3731865 correlated with the overall expression of SLC11A1 and also with the isoform ratio in whole blood samples collected in PAXgene RNA tubes from 42 healthy donors recruited from Cambridge BioResource (CBR) [54]. It was hypothesised that in donors homozygous for the T1D susceptibility allele, there would be increased levels of transcripts without exon $4 \mathrm{a}$, which codes for functional protein, and less of the alternative transcript, which encodes premature stop codons and, thus, a nonfunctional protein. Thereby an overall higher splice isoform ratio is expected in individuals homozygous for the susceptibility allele compared to individuals homozygous for the protective allele. However, no genotype effect was detected for expression of $S L C 11 A 1$ overall or for isoform ratio differences $(P=0.92$ and 0.70 , respectively; Figure 2).

The failure to detect SLC11A1 expression differences based on rs3731865 genotypes could be due to various reasons, such as there is actually no correlation between its transcriptional splicing and genotypes of rs3731865 in whole blood, or there is, but the quantitative PCR (qPCR) assays are not sensitive enough to detect it, or perhaps the current sample size may not be large enough to have sufficient power to detect a small difference. It is also possible that a purified cell subset should be studied instead of analysing overall expression in whole blood, such as monocyte-derived macrophages, where the gene is known to function.

The incidence of T1D is predicted to double in children under 5 years by 2020 [55], with the likely cause being the changing environment. These environmental changes could impact our association study, with geneenvironment interactions becoming increasingly important. Our control cohort is of similar age to the parents of our cases. This single generational difference could still reduce our power to find effects in our case-control study in the presence of gene-environment interactions, owing to their differences in early life environmental exposures. However, this does not affect the significance of the findings obtained. Taking the data collectively, we identified the strongest allelic association with T1D at rs3731865 in intron 4 of SLC11A1. This SNP is also most associated with JIA in Finnish families in the same direction where the minor allele is also protective for disease [39]. Although the promoter microsatellite remains the only variant reported to date for which there is evidence of a correlation with function in the SLC11A1 gene region [43,51], alleles 2 and 3 of the microsatellite are in strong LD with $\mathrm{rs} 3731865\left(\mathrm{r}^{2}=\right.$ 0.79 in controls; see additional file 2). Therefore, any T1D association detected for the microsatellite might be tagging the association of rs3731865. The extensive prior evidence linking SLC11A1 function and expression with autoimmune, immune-related and infectious diseases in mice and humans, and the confirmed polygenic model of T1D inheritance of numerous small effects, suggest that $S L C 11 A 1$ variation may well have a very small effect on human T1D risk $[56,57]$.

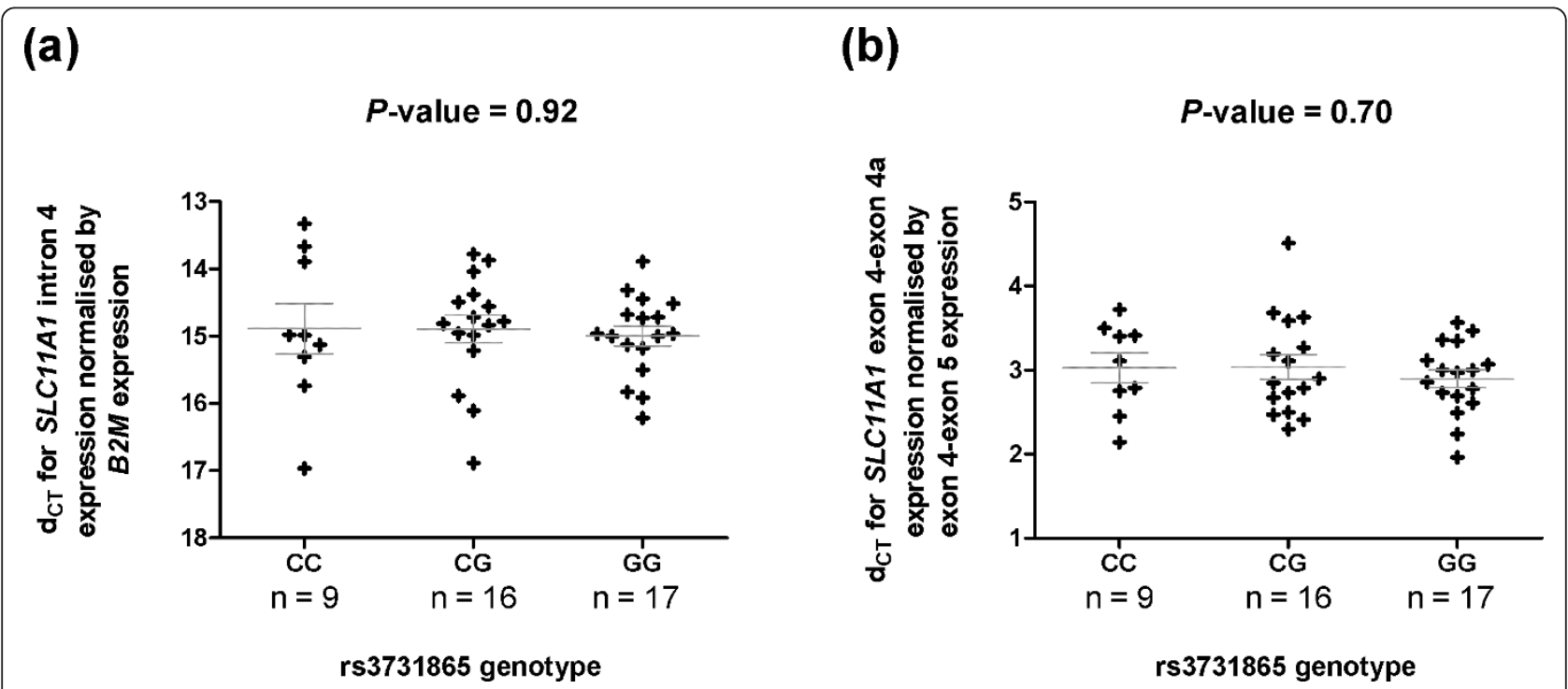

Figure 2 SLC11A1 expression by rs3731865 genotype. No genotype effect was detected either for (a) overall expression or for (b) the ratio of both isoforms. [C = minor protective allele and $\mathrm{G}=$ major susceptibility allele] 
A search for additional rare variants via next generation sequencing, as well as results coming from the 1000 Genomes Project [58], could provide further information regarding the possibility of an association of SLC11A1 with T1D. Recently, Zeller et al. and Heinig et al. performed a large-scale investigation of the transcriptome of circulating monocytes and monocytedifferentiated macrophages using the Illumina Human HT-12 expression BeadChips [14,59]. The two microarray probes (ILMN_1741165 and ILMN_1735737) in SLC11A1 mapped to the 3'UTR of the gene. Using the data from Heinig et al. a stronger expression signal is detected by the ILMN_1741165 probe compared to the other probe [14]. Although expression quantitative trait loci (eQTL) and eSNPs for SLC11A1 were identified from these studies for the ILMN_1741165 probe, including the T1D-associated SNP, rs4674297 $\left(P=1.03 \times 10^{-65}\right)$ [59], this probe maps to repeat sequences $[14,59]$. Therefore the eQTL identified for SLC11A1 is highly questionable and could be an artefact. Only about 39\% of eQTLs are likely to be due to "simple effect" SNPs, those that altered transcription levels [60]. The majority of eQTL variations are, however, owed to other alterations in gene expression, namely altered initiation/termination and/or splicing [60]. Hence, analysis of microarrays with multiple probes per gene and per exon e.g. Affymetrix Gene Array, and, in the future, direct RNA sequencing using the next generation technologies should be more informative. Investigating the correlation of SLC11A1 RNA expression and protein level in genotyped human macrophage/stimulated monocyte or DC samples based on the genotype/haplotype of the most T1D-associated variant(s) would help to prove causality of the genes in human T1D and help to identify biological disease mechanisms involved in pathogenesis of T1D.

\section{Conclusion}

We conclude that genetic variation of the SLC11A1 gene could possibly be associated with T1D susceptibility. We did not observe a difference in SLC11A1 expression at the RNA level based on the genotypes of the SNP most associated with T1D, rs3731865 (INT4), in whole blood samples. However, a potential correlation cannot be ruled out in purified blood cell subsets.

\section{Methods \\ Subjects}

We genotyped a maximum of 8,863 T1D cases and 10,841 controls of self-reported white ethnicity collected from across Great Britain, with non-European subjects excluded by GWAS genotyping results (see Genetic association statistical analysis). All cases were recruited as part of the Juvenile Diabetes Research Foundation/ Wellcome Trust Diabetes and Inflammation Laboratory U.K. Genetic Resource Investigating Diabetes (GRID) study [61]. All cases were diabetic defined using the WHO criteria. Most were less than 16 years of age at the time of collection and all were diagnosed before 17 years of age, with a mean age-at-diagnosis of 7.8 years. Controls were obtained from the British 1958 Birth Cohort ( $\mathrm{n}=7,658$ [62]) and the UK Blood Service's collaboration with the WTCCC $(n=3,183$ [63]). A collection of 5,696 families of European ancestry were also genotyped. These included 470 multiplex families from the Diabetes UK Warren 1 repository, 263 simplex families from Northern Ireland, 80 simplex families from Yorkshire, 734 simplex families from Finland, 360 simplex families from Norway, 423 simplex families from Romania, 335 multiplex families from the Human Biological Data Interchange (U.S.) and 3,031 families made available through the T1DGC [64]. The T1DGC families comprised of 362 families from the Asia-Pacific region, 873 families from across Europe, 1,633 from North America and 163 from the U.K. [65]. All families had samples from both parents and at least one affected child. Families exhibiting misinheritances were excluded. All DNA samples were collected with approval from the relevant research ethics committees and written informed consent was obtained from the participants or their guardians, if they were too young to consent.

PAXgene whole blood samples were obtained from 42 healthy subjects of self-reported white ethnicity with nonautoimmune disease status from the Cambridge BioResource (CBR) [54] and selected by SLC11A1 genotype. T1D patients were excluded in this study to avoid any confounding due to T1D status or to insulin treatment. Informed consent was obtained from all volunteers upon recruitment to the CBR for the collection and use of DNA samples for genotyping. Ethical approval for this study was given by the Cambridgeshire 3 Research Ethics Committee and an informed consent was obtained for the collection and use of the fresh peripheral blood samples.

\section{Genotyping}

Nine SNPs (rs2276631, rs2279015, rs1809231, rs1059823, rs17235409, rs17235416, rs3731865, rs7573065 and rs4674297) were genotyped using Custom TaqMan ${ }^{\circledR}$ SNP Genotyping Assays (Applied Biosystems (ABI)) according to manufacturers' protocols. The microsatellite (GT)n was amplified using AmpliTaq ${ }^{\circledR}$ (ABI) using 5 FAM labelled forward primer (5'-6ttcaatgcatgtcccttctg-3') and reverse primer ( $5^{\prime}$-ccatggagtggacctttgtt-3') in $6 \mu \mathrm{l}$ reaction volume with the following PCR conditions: an initial denaturation at $95^{\circ} \mathrm{C}$ for 5 minutes, then 25 cycles of denaturation at $94^{\circ} \mathrm{C}$ for 30 seconds, annealing at $65^{\circ} \mathrm{C}$ for 30 seconds and extension at $72^{\circ} \mathrm{C}$ for 30 seconds, with a final extension at $72^{\circ} \mathrm{C}$ for 10 minutes. $2 \mu \mathrm{l}$ of PCR amplified product was added to $10 \mu \mathrm{l}$ of pre-diluted GeneScan LIZ500 size standard $(25 \mu \mathrm{l}$ of LIZ500 in $1 \mathrm{ml}$ of 
Hi-Di Formamide; ABI) and heated at $95^{\circ} \mathrm{C}$ for 5 minutes before being resolved on ABI PRISM 3730XL Genetic Analyzer (ABI) and scored on GeneMapper v.4.0 software $(\mathrm{ABI})$.

Case and control DNA samples were distributed evenly on 384-well plates for genotyping. All genotyping data were scored by one researcher and reviewed by a second to minimise error. Both researchers were unaware of case-control status and family structure. 58 out of 2,275 96-well case-control DNA plates $(2.5 \%)$ in this experiment had some scoring differences, 29 in one well only, and with only one DNA plate (of whole genomeamplified samples) requiring substantial review. Genotyping success rates ranged from $93.3 \%$ to $97.5 \%$ for the nine SNPs and the microsatellite (GT)n. Across the full case-control collection, there were a maximum of 298 duplicates, the majority (262) being control samples that have been submitted twice. There were no duplicates in the family collections. Across the nine SNPs and the microsatellite the overall concordance rates were $99.6 \%$ and $96.9 \%$, respectively. Hardy-Weinberg equilibrium was calculated on a plate-by-plate basis in addition to the entire case and control samples to highlight any erroneous plates. Genotypes of rs1059823 were found to deviate significantly from Hardy-Weinberg equilibrium in the controls $(P=0.001)$ and, therefore, rs1059823 was not tested for association with T1D using the casecontrol collection.

\section{Genetic association statistical analysis}

All statistical analyses were performed in the statistical package, STATA v10.0 [66]. There was no difference in allele frequencies between the two control cohorts [53]. Most of the samples used here have also been part of a GWAS and as such have been subjected to rigorous testing for population heterogeneity $[1,53]$. Any nonCaucasian and related individuals identified through previous GWAS have also been removed $[1,53,56,67,68]$. Association with T1D was tested using logistic regression models. Cases and controls were matched according to 12 broad geographical subregions of England, Scotland and Wales (Southwestern, Southern, Southeastern, London, Eastern, Wales, Midlands, North Midlands, Northwestern, East and West Riding, Northern, and Scotland), based on the place of recruitment and the place of birth, respectively, to minimise confounding due to geographical differences in allele frequency and disease incidence. Each genetic variant was first tested for association using a multiplicative allelic effects model on one degree of freedom (df), with counts of the minor allele, coded $0,1,2$, as the dependent variable, disease status as the outcome variable and geographical subregions included as strata. Each variant was tested using a genotype effects model (on two df) that did not assume a specific inheritance model. The genotype and allelic effects models were compared using a likelihood ratio test. Except for rs1809231, the multiplicative allelic effects model was reported as it was not significantly different from the genotype effects model $(P>0.05)$.

Although the reported $P$-values were not adjusted for multiple testing, the $P$-value threshold required for statistical significance was adjusted. We performed nine independent tests and so only considered an association significant if $P \leq 0.005$. Power calculations for the genetic association analyses for the case-control dataset was performed using CaTS as described in Skol et al. [69], and for the family datasets, using the method developed by Knapp [70].

Forward logistic regression analyses were performed to test for associations with T1D that were independent of the effect of rs3731865, in other words, evidence against the most significant SNP, rs3731865, being sufficient to model the association in the SLC11A1 region [71]. Each variant in turn was added to a model that included rs3731865, and a likelihood ratio test was used to assess whether there was an additional independent effect.

To estimate the joint effects of the microsatellite (GT) $\mathrm{n}$ and $\operatorname{rs7573065}(-237 \mathrm{C} \rightarrow \mathrm{T}$ SNP), both variants were included in the logistic regression model, under the assumption of multiplicative allelic effects.

Haplotype logistic regression analysis was also carried out for the microsatellite (GT)n and rs7573065 (-237 $\mathrm{C} \rightarrow \mathrm{T}$ SNP). Phased haplotypes were generated under the null hypothesis that case and control haplotypes were drawn from the same population using the SNPHAP program, version 1.3.1. 1,000 Expectation Maximum (EM) iterations were used, each started from a random imputation, and only using samples genotyped at both loci. Haplotypes were tested for association in a logistic regression model, where haplotype assignments were weighted by their posterior probabilities, and robust variance estimates were used to account for nonindependence when multiple haplotype assignments were possible for each subject.

The transmission/disequilibrium test (TDT) was used to analyse family data for association with disease [72].

\section{SLC11A1 gene expression assays}

Whole blood samples from 42 healthy CBR donors were collected directly into PAXgene Blood RNA tubes (PreAnalytiX). RNA was extracted on the day of blood sample collection using the PAXgene Blood RNA kit (QIAGEN/ BD) with DNase I treatment according to manufacturers' protocols. $1 \mu \mathrm{g}$ of total RNA was used for each reverse transcription (RT) reaction for synthesising cDNA primed with oligo dT primer (18-mer) using Superscript $^{\mathrm{TM}}$ III (Invitrogen) according to manufacturers' instructions. To assess whether RNA samples were 
contaminated with genomic DNA, a corresponding RTnegative control template was set up for each RT reaction. A qPCR assay designed to amplify genomic DNA was used to detect DNA contamination within the RTnegative control sample. SLC11A1 qPCR assays were designed using Primer3Plus software [73] and checked for specificity using the Basic Local Alignment Search Tool (BLAST; see additional file 3 for primer and probe sequences). qPCR reactions were run in MicroAmp ${ }^{\mathrm{TM}}$ Optical 384-well plates (ABI) in a total reaction volume of $20 \mu \mathrm{l}$ containing $2 \mu \mathrm{l}$ of cDNA sample, $0.6 \mu \mathrm{l}$ of $10 \mu \mathrm{M}$ forward and reverse primers each, $0.8 \mu \mathrm{l}$ of $5 \mu \mathrm{M}$ probe, $10 \mu \mathrm{l}$ of TaqMan Universal PCR Master Mix (ABI) and $6 \mu \mathrm{l}$ of $\mathrm{dH}_{2} \mathrm{O}$. The thermal cycling conditions started with $50^{\circ} \mathrm{C}$ for 2 minutes, initial denaturation at $95^{\circ} \mathrm{C}$ for 10 minutes, followed by 40-50 cycles of denaturation at $95^{\circ} \mathrm{C}$ for 15 seconds and annealing/extension at $60^{\circ} \mathrm{C}$ for 1 minute. Samples were run in duplicates on the same plate, and fluorescent signals detected using an ABI $7900 \mathrm{HT}$ plate reader (ABI) with SDS v2.2.2 software (ABI). Data was analysed using comparative cycle number $\left(\mathrm{C}_{\mathrm{T}}\right)$ method, averaged and normalised by the endogenous $B 2 M$ control ran on the same plate. Correlations between SLC11A1 overall gene expression and splice isoform ratio with rs3731865 genotypes were tested using ANOVA using the GraphPad Prism software.

\section{Additional material}

Additional file 1: Sequences of the human SLC11A1 polymorphic microsatellite and the allele frequencies in controls

Additional file 2: The pair-wise linkage disequilibrium (as measured by $r^{2}$ and $D^{\prime}$ ) between the genotyped variants in the SLC11A1 gene region using the genotyping data from 10,841 controls

Additional file 3: Quantitative PCR primer and probe sequences.

\section{Acknowledgements}

We thank the Wellcome Trust, the Juvenile Diabetes Research Foundation (JDRF) and the National Institute for Health Research (NIHR) for funding the Diabetes and Inflammation Laboratory. We gratefully acknowledge the participation of all the patients, control subjects, family members and CBR donors. We thank David Dunger, Barry Widmer, and the British Society for Paediatric Endocrinology and Diabetes for the T1D case collection. We acknowledge use of the DNA from the 1958 British Birth Cohort collection, funded by the MRC (grant G0000934) and the Wellcome Trust (grant 068545/Z/02), and we thank D. Strachan and P. Burton for their help. We also thank The Avon Longitudinal Study of Parents and Children laboratory in Bristol, including S. Ring, R. Jones, M. Pembrey, W. McArdle, D. Strachan and P. Burton for preparing and providing the control DNA samples. We acknowledge use of DNA from The UK Blood Services collection of Common Controls (UKBS collection), funded by the Wellcome Trust (grant 076113/C/04/Z), the JDRF (grant WT061858) and the NIHR of England. The collection was established as part of the Wellcome Trust Case-Control Consortium.

We acknowledge use of DNA from the Human Biological Data Interchange and Diabetes UK for the USA and UK multiplex families, respectively; the Norwegian Study Group for Childhood Diabetes (D. Undlien and K. Ronningen) for the Norwegian families; D. Savage, C. Patterson, D. Carson and P. Maxwell for the Northern Irish families; the Genetics of Type 1 Diabetes in Finland (GET1FIN), J. Tuomilehto, L. Kinnunen, E. TuomilehtoWolf, V. Harjutsalo and T. Valle for the Finnish families; and C. Guja and C. Ionescu-Tirgoviste for the Romanian families. This research utilised resources provided by the T1DGC, a collaborative clinical study sponsored by the National Institute of Diabetes and Digestive and Kidney Diseases (NIDDK), National Institute of Allergy and Infectious Diseases (NIAID), National Human Genome Research Institute (NHGRI), National Institute of Child Health and Human Development (NICHD) and the JDRF, and supported by U01 DK062418.

We thank the NIHR Cambridge Biomedical Research Centre (CBRC) and the MRC Cusrow Wadia for funding of the CBR. We thank members of the CBR Management Committee and Scientific Advisory Board. We thank K. Beer, P. Tagart and M. Wiesner for blood sample collection and M. Woodburn and T. Attwood for their contribution to sample management.

We thank V. Everett and W. Giel for information technology support. We also thank P. Clarke, G. Coleman, J. Denesha, S. Duley, D. Harrison, S. Hawkins, M. Maisuria-Armer, T. Mistry and N. Taylor for preparation of DNA samples. The Cambridge Institute for Medical Research is in receipt of a Wellcome Trust Strategic Award (079895). JHMY was supported by the MRC studentship.

\section{Authors' contributions}

JHMY performed SNP genotyping, statistical analyses, whole blood sample processing, qPCR, collated the data, generated tables and figures and writing the manuscript. KD contributed to whole blood sample processing. JMMH assisted with statistical analysis and helped to draft the manuscript. SN and JAT are members of the CBR Management Committee who had a primary role in the creation and management of the CBR. HES was responsible for the DNA sample management. NMW managed the data. JAT participated in the conception and design of the study, analysed results and helped to draft the manuscript. All authors read and approved the final manuscript.

\section{Competing interests}

The authors declare that they have no competing interests.

Received: 16 July 2010 Accepted: 27 April 2011 Published: 27 April 2011

\section{References}

1. Barrett JC, Clayton DG, Concannon P, Akolkar B, Cooper JD, Erlich HA, Julier C, Morahan G, Nerup J, Nierras C, Plagnol V, Pociot F, Schuilenburg H, Smyth DJ, Stevens H, Todd JA, Walker NM, Rich SS: Genome-wide association study and meta-analysis find that over 40 loci affect risk of type 1 diabetes. Nat Genet 2009, 41(6):703-707.

2. Cooper JD, Smyth DJ, Smiles AM, Plagnol V, Walker NM, Allen JE, Downes K, Barrett JC, Healy BC, Mychaleckyj JC, Warram JH, Todd JA: Meta-analysis of genome-wide association study data identifies additional type 1 diabetes risk loci. Nat Genet 2008, 40(12):1399-1401.

3. T1DBase. [https://www.t1dbase.org/page/Welcome/display].

4. Maier L, Smyth D, Vella A, Payne F, Cooper J, Pask R, Lowe C, Hulme J, Smink L, Fraser H, Moule C, Hunter K, Chamberlain G, Walker N, Nutland S, Undlien D, Ronningen K, Guja C, Ionescu-Tirgoviste C, Savage D, Strachan D, Peterson L, Todd J, Wicker L, Twells R: Construction and analysis of tag single nucleotide polymorphism maps for six humanmouse orthologous candidate genes in type 1 diabetes. BMC Genetics 2005, 6(1):9.

5. Hill NJ, Lyons PA, Armitage N, Todd JA, Wicker LS, Peterson LB: NOD Idd5 locus controls insulitis and diabetes and overlaps the orthologous CTLA4/IDDM12 and NRAMP1 loci in humans. Diabetes 2000, 49(10):1744-1747.

6. Wicker LS, Chamberlain G, Hunter K, Rainbow D, Howlett S, Tiffen P, Clark J, Gonzalez-Munoz A, Cumiskey AM, Rosa RL, Howson JM, Smink LJ, Kingsnorth A, Lyons PA, Gregory S, Rogers J, Todd JA, Peterson LB: Fine Mapping, Gene Content, Comparative Sequencing, and Expression Analyses Support Ctla4 and Nramp1 as Candidates for Idd5.1 and Idd5.2 in the Nonobese Diabetic Mouse. J Immunol 2004, 173(1):164-173.

7. Kissler S, Stern P, Takahashi K, Hunter K, Peterson LB, Wicker LS: In vivo RNA interference demonstrates a role for Nramp1 in modifying susceptibility to type 1 diabetes. Nat Genet 2006, 38(4):479-483. 
8. Dai YD, Marrero IG, Gros P, Zaghouani H, Wicker LS, Sercarz EE: Slc11a1 Enhances the Autoimmune Diabetogenic T-cell Response by Altering Processing and Presentation of Pancreatic Islet Antigens. Diabetes 2008, db07-1608.

9. Cellier M, Govoni G, Vidal S, Kwan T, Groulx N, Liu J, Sanchez F, Skamene E, Schurr E, Gros P: Human natural resistance-associated macrophage protein: CDNA cloning, chromosomal mapping, genomic organization, and tissue-specific expression. J Exp Med 1994, 180(5):1741-1752.

10. BioGPS. [http://biogps.gnf.org]

11. HaemAtlas. [http://dil.t1dbase.org/page/HaemAtlasView].

12. Blackwell JM: Structure and function of the natural-resistance-associated macrophage protein (Nramp1), a candidate protein for infectious and autoimmune disease susceptibility. Mol Med Today 1996, 2(5):205-211.

13. Blackwell JM, Searle S, Goswami T, Miller EN: Understanding the multiple functions of Nramp1. Microbes Infect 2000, 2(3):317-321.

14. Heinig M, Petretto E, Wallace $C$, Bottolo L, Rotival M, Lu H, Li Y, Sarwar R, Langley SR, Bauerfeind A, Hummel O, Lee YA, Paskas S, Rintisch C, Saar K, Cooper J, Buchan R, Gray EE, Cyster JG, Braund P, Gracey J, Krishnan U, Moore JS, Nelson CP, Pollard H, Attwood T, Crisp-Hihn A, Foad N, Jolley J, Lloyd-Jones $\mathrm{H}$, et al: A trans-acting locus regulates an anti-viral expression network and type 1 diabetes risk. Nature 2010, 467(7314):460-4

15. Willcox A, Richardson SJ, Bone AJ, Foulis AK, Morgan NG: Analysis of islet inflammation in human type 1 diabetes. Clin Exp Immunol 2009, 155(2):173-181.

16. Richardson S, Willcox A, Bone A, Morgan N, Foulis A: Immunopathology of the human pancreas in type-I diabetes. Seminars in Immunopathology 2010, 1-13.

17. Fritsche G, Nairz M, Werner ER, Barton HC, Weiss G: Nramp1-functionality increases iNOS expression via repression of IL-10 formation. European Journal of Immunology 2008, 38(11):3060-3067.

18. Todd JA: Etiology of type 1 diabetes. Immunity 2010, 32(4):457-467.

19. Franke A, Balschun $T$, Karlsen $T H$, Sventoraityte J, Nikolaus S, Mayr G, Domingues FS, Albrecht M, Nothnagel M, Ellinghaus D, Sina C, Onnie CM, Weersma RK, Stokkers PCF, Wijmenga C, Gazouli M, Strachan D, McArdle WL, Vermeire $S$, Rutgeerts $P$, Rosenstiel $P$, Krawczak M, Vatn MH, Mathew CG, Schreiber S: Sequence variants in IL10, ARPC2 and multiple other loci contribute to ulcerative colitis susceptibility. Nat Genet 2008, 40(11):1319-1323.

20. Gateva V, Sandling JK, Hom G, Taylor KE, Chung SA, Sun X, Ortmann W, Kosoy R, Ferreira RC, Nordmark G, Gunnarsson I, Svenungsson E, Padyukov L, Sturfelt G, Jonsen A, Bengtsson AA, Rantapaa-Dahlqvist S, Baechler EC, Brown EE, Alarcon GS, Edberg JC, Ramsey-Goldman R, McGwin G, Reveille JD, Vila LM, Kimberly RP, Manzi S, Petri MA, Lee A, Gregersen PK, et al: A large-scale replication study identifies TNIP1, PRDM1, JAZF1, UHRF1BP1 and IL10 as risk loci for systemic lupus erythematosus. Nat Genet 2009, 41(11):1228-1233.

21. Greenwood CM, Fujiwara TM, Boothroyd $L$, Miller MA, Frappier D, Fanning EA, Schurr E, Morgan K: Linkage of tuberculosis to chromosome 2q35 loci, including NRAMP1, in a large aboriginal Canadian family. Am J Hum Genet 2000, 67(2):405-416.

22. Li HT, Zhang TT, Zhou YQ, Huang QH, Huang J: SLC11A1 (formerly NRAMP1) gene polymorphisms and tuberculosis susceptibility: a metaanalysis. Int J Tuberc Lung Dis 2006, 10(1):3-12

23. Bellamy R, Ruwende C, Corrah T, McAdam KP, Whittle HC, Hill AV: Variations in the NRAMP1 gene and susceptibility to tuberculosis in West Africans. N Engl J Med 1998, 338(10):640-644.

24. Gao PS, Fujishima S, Mao XQ, Remus N, Kanda M, Enomoto T, Dake Y, Bottini N, Tabuchi M, Hasegawa N, Yamaguchi K, Tiemessen C, Hopkin JM, Shirakawa T, Kishi F: Genetic variants of NRAMP1 and active tuberculosis in Japanese populations. International Tuberculosis Genetics Team. Clin Genet 2000, 58(1):74-76.

25. Cervino AC, Lakiss S, Sow O, Hill AV: Allelic association between the NRAMP1 gene and susceptibility to tuberculosis in Guinea-Conakry. Ann Hum Genet 2000, 64(Pt 6):507-512.

26. Mohamed HS, Ibrahim ME, Miller EN, White JK, Cordell HJ, Howson JM, Peacock CS, Khalil EA, El Hassan AM, Blackwell JM: SLC11A1 (formerly NRAMP1) and susceptibility to visceral leishmaniasis in The Sudan. Eur J Hum Genet 2004, 12(1):66-74

27. Taype CA, Castro JC, Accinelli RA, Herrera-Velit P, Shaw MA, Espinoza JR: Association between SLC11A1 polymorphisms and susceptibility to different clinical forms of tuberculosis in the Peruvian population. Infection, Genetics and Evolution 2006, 6(5):361-367.

28. Velez DR, Hulme WF, Myers JL, Stryjewski ME, Abbate E, Estevan R, Patillo SG, Gilbert JR, Hamilton CD, Scott WK: Association of SLC11A1 with tuberculosis and interactions with NOS2A and TLR2 in African-Americans and Caucasians. Int J Tuberc Lung Dis 2009, 13(9):1068-1076.

29. Castellucci L, Jamieson SE, Miller EN, Menezes E, Oliveira J, Magalhaes A Guimaraes LH, Lessa M, de Jesus AR, Carvalho EM, Blackwell JM: CXCR1 and SLC11A1 polymorphisms affect susceptibility to cutaneous leishmaniasis in Brazil: a case-control and family-based study. BMC Med Genet 2010, 11:10.

30. Bassuny W, Ihara K, Matsuura N, Ahmed S, Kohno H, Kuromaru R, Miyako K, Hara T: Association study of the NRAMP1 gene promoter polymorphism and early-onset type 1 diabetes. Immunogenetics 2002, 54(4):282-285.

31. Esposito L, Hill NJ, Pritchard LE, Cucca F, Muxworthy C, Merriman ME, Wilson A, Julier C, Delepine M, Tuomilehto J, Tuomilehto-Wolf E, lonescoTirgoviste C, Nistico L, Buzzetti R, Pozzilli P, Ferrari M, Bosi E, Pociot F, Nerup J, Bain SC, Todd JA: Genetic analysis of chromosome 2 in type 1 diabetes: analysis of putative loci IDDM7, IDDM12, and IDDM13 and candidate genes NRAMP1 and IA-2 and the interleukin-1 gene cluster. IMDIAB Group. Diabetes 1998, 47(11):1797-1799.

32. Nishino M, Ikegami $H$, Fujisawa $T$, Kawaguchi $Y$, Kawabata $Y$, Shintani M, Ono M, Ogihara T: Functional polymorphism in Z-DNA-forming motif of promoter of SLC11A1 gene and type 1 diabetes in Japanese subjects: Association study and meta-analysis. Metabolism 2005, 54(5):628-633.

33. Paccagnini D, Sieswerda L, Rosu V, Masala S, Pacifico A, Gazouli M, Ikonomopoulos J, Ahmed N, Zanetti S, Sechi LA: Linking chronic infection and autoimmune diseases: Mycobacterium avium subspecies paratuberculosis, SLC11A1 polymorphisms and type-1 diabetes mellitus. PLOS ONE 2009, 4(9):e7109.

34. Shaw MA, Clayton D, Atkinson SE, Williams H, Miller N, Sibthorpe D, Blackwell JM: Linkage of rheumatoid arthritis to the candidate gene NRAMP1 on 2q35. J Med Genet 1996, 33(8):672-677.

35. Singal DP, Li J, Zhu Y, Zhang G: NRAMP1 gene polymorphisms in patients with rheumatoid arthritis. Tissue Antigens 2000, 55(1):44-47.

36. Yang YS, Kim SJ, Kim JW, Koh EM: NRAMP1 gene polymorphisms in patients with rheumatoid arthritis in Koreans. J Korean Med Sci 2000, 15(1):83-87.

37. Ates Ö, Dalyan L, Müsellim B, Hatemi G, Türker H, Öngen G, Hamuryudan V, Topal-Sarıkaya A: NRAMP1 (SLC11A1) gene polymorphisms that correlate with autoimmune versus infectious disease susceptibility in tuberculosis and rheumatoid arthritis. International Journal of Immunogenetics 2009, 36(1):15-19.

38. Sanjeevi CB, Miller EN, Dabadghao P, Rumba I, Shtauvere A, Denisova A Clayton D, Blackwell JM: Polymorphism at NRAMP1 and D2S1471 loci associated with juvenile rheumatoid arthritis. Arthritis Rheum 2000 43(6):1397-1404

39. Runstadler JA, Saila H, Savolainen A, Leirisalo-Repo M, Aho K, TuomilehtoWolf E, Tuomilehto J, Seldin MF: Association of SLC11A1 (NRAMP1) with persistent oligoarticular and polyarticular rheumatoid factor-negative juvenile idiopathic arthritis in Finnish patients: haplotype analysis in Finnish families. Arthritis Rheum 2005, 52(1):247-256.

40. Maliarik MJ, Chen KM, Sheffer RG, Rybicki BA, Major ML, Popovich J Jr, lannuzzi MC: The natural resistance-associated macrophage protein gene in African Americans with sarcoidosis. Am J Respir Cell Mol Biol 2000 22(6):672-675

41. Hofmeister A, Neibergs HL, Pokorny RM, Galandiuk S: The natural resistance-associated macrophage protein gene is associated with Crohn's disease. Surgery 1997, 122(2):173-178, discussion 178-179.

42. Kojima Y, Kinouchi Y, Takahashi S, Negoro K, Hiwatashi N, Shimosegawa T: Inflammatory bowel disease is associated with a novel promoter polymorphism of natural resistance-associated macrophage protein 1 (NRAMP1) gene. Tissue Antigens 2001, 58(6):379-384.

43. Gazouli M, Atsaves V, Mantzaris G, Economou M, Nasioulas G, Evangelou K, Archimandritis AJ, Anagnou NP: Role of functional polymorphisms of NRAMP1 gene for the development of Crohn's disease. Inflamm Bowel Dis 2008, 14(10):1323-1330.

44. Zaahl MG, Winter TA, Warnich L, Kotze MJ: The $-237 \mathrm{C}->$ T promoter polymorphism of the SLC11A1 gene is associated with a protective effect in relation to inflammatory bowel disease in the South African population. Int J Colorectal Dis 2006, 21(5):402-408. 
45. Kotlowski R, Bernstein CN, Silverberg MS, Krause DO: Population-based case-control study of alpha 1-antitrypsin and SLC11A1 in Crohn's disease and ulcerative colitis. Inflamm Bowel Dis 2008, 14(8):1112-1117.

46. Ouchi K, Suzuki Y, Shirakawa T, Kishi F: Polymorphism of SLC11A1 (Formerly NRAMP1) Gene Confers Susceptibility to Kawasaki Disease. The Journal of Infectious Diseases 2003, 187(2):326-329.

47. Kotze MJ, de Villiers JNP, Rooney RN, Grobbelaar JJ, Mansvelt EPG, Bouwens CSH, Carr J, Stander I, du Plessis L: Analysis of the NRAMP1 Gene Implicated in Iron Transport: Association with Multiple Sclerosis and Age Effects. Blood Cells, Molecules, and Diseases 2001, 27(1):44-53.

48. Ates O, Dalyan L, Hatemi G, Hamuryudan V, Topal-Sarikaya A: Genetic susceptibility to Behcet's syndrome is associated with NRAMP1 (SLC11A1) polymorphism in Turkish patients. Rheumatol Int 2009, 29(7):787-791

49. Zaahl MG, Warnich L, Victor TC, Kotze MJ: Association of functional polymorphisms of SLC11A1 with risk of esophageal cancer in the South African Colored population. Cancer Genetics and Cytogenetics 2005, 159(1):48-52.

50. Blackwell JM, Barton $\mathrm{CH}$, White JK, Searle S, Baker AM, Williams H, Shaw MA Genomic organization and sequence of the human NRAMP gene: identification and mapping of a promoter region polymorphism. Mol Med 1995, 1(2):194-205

51. Searle $S$, Blackwell JM: Evidence for a functional repeat polymorphism in the promoter of the human NRAMP1 gene that correlates with autoimmune versus infectious disease susceptibility. J Med Genet 1999, 36(4):295-299

52. Zaahl MG, Robson KJH, Warnich L, Kotze MJ: Expression of the SLC11A1 (NRAMP1) 5'-(GT)n repeat: Opposite effect in the presence of $-237 \mathrm{C}->\mathrm{T}$. Blood Cells, Molecules, and Diseases 2004, 33(1):45-50.

53. The Wellcome Trust Case Control Consortium: Genome-wide association study of 14,000 cases of seven common diseases and 3,000 shared controls. Nature 2007, 447(7145):661-678.

54. Cambridge BioResource. [http://www.cambridgebioresource.org.uk]].

55. Patterson CC, Dahlquist GG, Gyurus E, Green A, Soltesz G: Incidence trends for childhood type 1 diabetes in Europe during 1989-2003 and predicted new cases 2005-20: a multicentre prospective registration study. Lancet 2009, 373(9680):2027-2033.

56. Todd JA, Walker NM, Cooper JD, Smyth DJ, Downes K, Plagnol V, Bailey R, Nejentsev S, Field SF, Payne F, Lowe CE, Szeszko JS, Hafler JP, Zeitels L, Yang JHM, Vella A, Nutland S, Stevens HE, Schuilenburg H, Coleman G, Maisuria M, Meadows W, Smink L, Healy B, Burren OS, Lam AAC, Ovington NR, Allen J, Adlem E, Leung H-T, et al: Robust associations of four new chromosome regions from genome-wide analyses of type 1 diabetes. Nat Genet 2007, 39(7):857-864

57. Wang WYS, Barratt BJ, Clayton DG, Todd JA: Genome-wide association studies: theoretical and practical concerns. Nat Rev Genet 2005, 6(2):109-118

58. 1000 Genomes Project. [http://www.1000genomes.org/].

59. Zeller T, Wild P, Szymczak S, Rotival M, Schillert A, Castagne R, Maouche $\mathrm{S}$, Germain M, Lackner K, Rossmann H, Eleftheriadis M, Sinning CR, Schnabel RB, Lubos E, Mennerich D, Rust W, Perret C, Proust C, Nicaud V, Loscalzo J, Hubner N, Tregouet D, Munzel T, Ziegler A, Tiret L, Blankenberg S, Cambien F: Genetics and beyond-the transcriptome of human monocytes and disease susceptibility. PLOS ONE 2010, 5(5):e10693.

60. Kwan T, Benovoy D, Dias C, Gurd S, Provencher C, Beaulieu P, Hudson TJ, Sladek R, Majewski J: Genome-wide analysis of transcript isoform variation in humans. Nat Genet 2008, 40(2):225-231.

61. U.K. GRID (Genetic Resource Investigating Diabetes) study. [http://www. childhood-diabetes.org.uk/grid.shtml].

62. British 1958 Birth Cohort. [http://www.b58cgene.sgul.ac.uk]

63. UK Blood Service involvement in human genetics. [http://www.wellcome. ac.uk/News/Media-office/Press-releases/2005/WTX026809.htm]

64. Type 1 Diabetes Genetics Consortium. [https://www.t1dgc.org/].

65. JDRF/WT DIL sample collection. [http://www-gene.cimr.cam.ac.uk/todd/ dna-refs.shtml].

66. STATA statistical package. [http://www.stata.com].

67. Smyth DJ, Cooper JD, Bailey R, Field S, Burren O, Smink LJ, Guja C, IonescuTirgoviste C, Widmer B, Dunger DB, Savage DA, Walker NM, Clayton DG, Todd JA: A genome-wide association study of nonsynonymous SNPS identifies a type 1 diabetes locus in the interferon-induced helicase (IFIH1) region. Nat Genet 2006, 38(6):617-619.
68. Clayton DG, Walker NM, Smyth DJ, Pask R, Cooper JD, Maier LM, Smink LJ, Lam AC, Ovington NR, Stevens HE, Nutland S, Howson JM, Faham M, Moorhead M, Jones HB, Falkowski M, Hardenbol P, Willis TD, Todd JA: Population structure, differential bias and genomic control in a largescale, case-control association study. Nat Genet 2005, 37(11):1243-1246.

69. Skol AD, Scott $L J$, Abecasis GR, Boehnke M: Joint analysis is more efficient than replication-based analysis for two-stage genome-wide association studies. Nat Genet 2006, 38(2):209-213.

70. Knapp M: A note on power approximations for the transmission/ disequilibrium test. Am J Hum Genet 1999, 64(4):1177-1185.

71. Cordell HJ, Clayton DG: A unified stepwise regression procedure for evaluating the relative effects of polymorphisms within a gene using case/control or family data: application to HLA in type 1 diabetes. Am $J$ Hum Genet 2002, 70(1):124-141.

72. Spielman RS, McGinnis RE, Ewens WJ: Transmission test for linkage disequilibrium: the insulin gene region and insulin-dependent diabetes mellitus (IDDM). Am J Hum Genet 1993, 52(3):506-516.

73. Primer3Plus software. [http://www.bioinformatics.nl/cgi-bin/primer3plus/ primer3plus.cgi].

\section{Pre-publication history}

The pre-publication history for this paper can be accessed here: http://www.biomedcentral.com/1471-2350/12/59/prepub

doi:10.1186/1471-2350-12-59

Cite this article as: Yang et al:: Evidence of association with type 1

diabetes in the SLC11A1 gene region. BMC Medical Genetics 2011 12:59.

\section{Submit your next manuscript to BioMed Central and take full advantage of:}

- Convenient online submission

- Thorough peer review

- No space constraints or color figure charges

- Immediate publication on acceptance

- Inclusion in PubMed, CAS, Scopus and Google Scholar

- Research which is freely available for redistribution

Submit your manuscript at www.biomedcentral.com/submit
C) Biomed Central 